\title{
VALIDITAS PENILAIAN KINERJA BERBASIS KOMPETENSI PERAWAT GAWAT DARURAT
}

\author{
Validity of the Assessment of Competency Based Performance of \\ Emergency Nurses
}

\author{
Gerry Silaban, Arfah Mardiana Lubis, Umi Salmah \\ Fakultas Kesehatan Masyarakat, Universitas Sumatera Utara \\ (gerry_fkmusu@yahoo.com)
}

\begin{abstract}
ABSTRAK
Saat ini, kompetensi dijadikan sebagai dasar untuk penilaian kinerja perawat di seluruh dunia, sehingga pada tahun 2015 telah dirancang sistem penilaian kinerja yang disusun berdasarkan kompetensi perawat gawat darurat. Namun, perlu dilakukan peninjauan kembali mengenai kevaliditasan sistem penilaian kinerja tersebut. Penelitian kuantitatif ini menggunakan rancangan pre and post-experimental, yang bertujuan memvalidasi rancangan penilaian kinerja berdasarkan kompetensi perawat gawat darurat yang telah dibuat pada tahun pertama. Populasi dari RSU Bina Kasih, RSU Malahayati, RSU Martha Friska, RSU Permata Bunda, RSU Sari Mutiara, RSU Deli Medan, dan RSU Imelda ada 63 orang berdasarkan purposive sampling. Penelitian dilakukan dari bulan Januari sampai Oktober 2016. Hasil uji Kolmogorov-Smirnov, sebaran data tidak normal (sig. Sebelum=0,003 $<\alpha=0,05$ dan Sig. Sesudah=0,002 $<\alpha=0,05$ ). Hasil uji wilcoxon, tidak ada perbedaan antara nilai rangking sebelum dan sesudah diaplikasikannya sistem penilaian kinerja $(\mathrm{p}=0,959)$. Oleh karena itu, sistem penilaian kinerja berdasarkan kompetensi perawat gawat darurat di RSU swasta se-Kota Medan dinyatakan valid.
\end{abstract}

Kata kunci : Penilaian kinerja, kompetensi, perawat gawat darurat

\section{ABSTRACT}

Currently, worldwide, competencies form the basis for nurse performance assessment, so that in the year 2015 a performance assessment system that is based on emergency nurses' competence. However, there should be a review of the validity of the performance assessment system. This quantitative study used a pre and post experimental design, which aimed to validate the design of the competency based performance assessment, which was made in the first year. The sample size was 63 people recruited using purposive sampling from RSU Bina Kasih, RSU Malahayati, RSU Martha Friska, RSU Permata Bunda, RSU Sari Mutiara, RSU Deli Medan, and $R S U$ Imelda. This research was conducted from January to October 2016. Results of a Kolmogorov-Smirnov test showed that the data distribution was not normal (Sig. Before $=0,003<\alpha=0,05$ and Sig. After $=0,002<\alpha=0,05$ ). Results of a Wilcoxon test found that there was nodifference in ranking before and after the competency based performance assessment was conducted $(p=0,959)$. Therefore, the assessment system for the competency based performance of emergency nurses in private general hospitals in Medan City was found to be valid.

Keywords : Performance assessment, competency, emergency nurse 


\section{PENDAHULUAN}

Banyak kasus kematian anak di rumah sakit terjadi dalam waktu 24 jam pertama pasien masuk ke rumah sakit. Pelayanan kesehatan yang memerlukan pelayanan segera, cepat, tepat dan cermat untuk mencegah kematian dan kecacatan adalah pelayanan pasien gawat darurat yang berada di Instalasi Gawat Darurat (IGD). Di dalam IGD, peran, fungsi dan tanggung jawab perawat sangat penting karena perawat sering dihadapkan pada kondisi ketika dokter tidak berada di tempat, maka mereka yang harus menilai pasien terlebih dahulu dan melakukan tindakan kegawatdaruratan. Oleh sebab itu, peningkatan kualitas kinerja dalam menjalankan profesinya sangat dituntut oleh pihak manajemen rumah sakit karena IGD merupakan citra bagi masyarakat tentang gambaran rumah sakit itu sebenarnya. ${ }^{1}$

Salah satu sistem atau proses penting dalam manajemen kinerja yang dilakukan bagian personalia di dalam rumah sakit adalah penilaian kinerja perawat gawat darurat. Bagi perawat gawat darurat sendiri, penilaian merupakan salah satu cara untuk mengetahui hasil dari usaha dan jerih payah sebagai kontribusi mereka terhadap kelangsungan rumah sakit, selain itu dengan adanya penilaian kinerja mereka juga dapat memiliki pandangan mengenai rencana karir bersama rumah sakit di masa yang akan datang. ${ }^{2,3,4}$

Saat ini, di seluruh dunia, kompetensi dijadikan dasar untuk penilaian kinerja perawat. ${ }^{5}$ Oleh karena itu, pada tahun 2015 telah dirancang sistem penilaian kinerja yang disusun berdasarkan kompetensi perawat gawat darurat. Kompetensi perawat gawat darurat di RSU Bina Kasih, RSU Malahayati, RSU Martha Friska, RSU Permata Bunda, RSU Sari Mutiara, dan RSU Deli Medan, adalah dampak dan pengaruh, mengembangkan orang lain, empati, percaya diri, pengendalian diri, komitmen terhadap organisasi, keahlian teknikal, berorientasi kepada pelanggan, kerjasama kelompok, berfikir analitis, berfikir konseptual, inisiatif dan proaktif, fleksibilitas, kemampuan mengarahkan perintah, semangat untuk berprestasi. Sedangkan kompetensi perawat gawat darurat di RSU Imelda adalah dampak dan pengaruh, mengembangkan orang lain, empati, percaya diri, pengendalian diri, komitmen terhadap organisasi, keahlian teknikal, berorientasi kepada pelanggan, kerja sama kelompok, berfikir analitis, berfikir konseptual, inisiatif dan proaktif, dan fleksibilitas. ${ }^{6} \mathrm{Na}-$ mun, perlu dilakukan peninjauan kembali sistem penilaian tersebut sudah valid atau belum.

Validasi merupakan langkah penting karena menguji keakuratan dari sistem yang dibuat pada tahun pertama kemudian membandingkannya dengan sistem yang telah ada sebelumnya. Jika sistem yang dibuat tahun pertama valid, maka sistem penilaian yang baru tersebut telah mampu untuk membedakan kinerja karyawan dengan lebih objektif dibandingkan dengan sistem penilaian kinerja yang lama. ${ }^{3,7}$

Berdasarkan hasil penelitian tahun pertama didapati dua rumah sakit tidak memiliki penilaian kinerja perawat gawat darurat, satu rumah sakit menggunakan critical incident technique (melihat kesesuaian kinerja perawat dengan Standar Operasional Prosedur), satu rumah sakit berfokus pada Task-Focused dimensions, satu rumah sakit berfokus pada Trait-Focused dimensions, satu rumah sakit berfokus pada Task-Focused dan Trait-Focused dimensions, dan dua rumah sakit berfokus pada Task-Focused, Trait-Focused dan Competency-Focused dimensions, tapi seluruhnya masih bersifat subjektifitas atasan. ${ }^{6}$

Perawat gawat darurat hanya dituntut untuk bekerja rajin dan jujur dan mereka bisa tetap bekerja pada rumah sakit tersebut jika tidak dilakukan penilaian kinerja. Subjektifitas atasan membuat hasil penilaian kinerja diragukan tingkat validitasnya. Lembar penilaian kinerja yang disusun menggunakan dimensi penilaian Task-Focused dan Trait-Focused akan membuat atasan yang menilai kurang dapat memberikan umpan balik yang sesuai dengan pengetahuan, kemampuan, keahlian dan karakteristik lain dari perawat gawat darurat. ${ }^{8,9,10}$ Oleh karena itu, tujuan penelitian pada tahun ke-dua ini adalah memvalidasi (concurrent construct validation) rancangan sistem penilaian kinerja berbasis kompetensi perawat gawat darurat, yang telah dibuat pada tahun pertama, yaitu atasan diminta untuk membuat urutan dengan menggunakan rating forms atau $Q$-sorts. ${ }^{11}$ Jika sistem penilaian kinerja ini valid, maka perawat gawat darurat yang berkinerja tertinggi pada penilaian sebelumnya (superstar), akan mendapatkan nilai tertinggi dalam rating forms dan tes. Kemudian jika sistem penilaian kinerja ini valid, 
dapat dipergunakan untuk rekrutmen, pendidikan, pelatihan dan promosi perawat gawat darurat di masing-masing Rumah Sakit Umum (RSU) Swasta di Kota Medan.

\section{BAHAN DAN METODE}

Penelitian kuantitatif ini menggunakan pre dan post eksperimen design. Populasi seluruh perawat gawat darurat di RSU Bina Kasih, RSU Malahayati, RSU Martha Friska, RSU Permata Bunda, RSU Sari Mutiara, RSU Deli Medan, dan RSU Imelda PM, berjumlah 63 orang. Teknik pengambilan sampel dengan purposive sampling, sampel diambil berdasarkan perbandingan 2:1,5 (2 orang tingkat kinerja tertinggi dan 1,5 orang tingkat kinerja rata-rata). Analisa data yang digunakan adalah analisis univariat dan bivariat. Uji yang digunakan adalah uji normalitas kolmogorov-smirnov dan uji wilcoxon. Penelitian dari bulan JanuariOktober 2016.

\section{HASIL}

Setiap atasan perawat gawat darurat di masing-masing RSU swasta terpilih, diminta untuk membuat urutan dengan menggunakan $\mathrm{ra}$ ting forms atau $Q$-sorts dari hasil penilaian. Contoh rating forms bisa dilihat pada lampiran dan hasil data bisa dilihat pada Tabel 1 . Hasil data tersebut kemudian dianalisa univariat dengan uji normalitas, oleh karena sampel lebih dari 50 (63 orang), maka yang digunakan adalah uji kolmogorov-smirnov. Hasil analisis menunjukkan bahwa nilai sig.sebelum $=0,003<\alpha=0,05$ dan sig.sesudah $=0,002<\alpha=0,05$, maka dapat disimpulkan sebaran data tidak normal. Oleh karena itu, dilanjutkan dengan analisis bivariat dengan uji wilcoxon untuk mengetahui perbedaan antara nilai rangking sebelum dan sesudah diaplikasikannya sistem penilaian kinerja berbasis kompetensi perawat gawat darurat.

Dari Tabel 2, dapat dilihat bahwa nilai $\mathrm{p}=0,959>0,05$. Oleh karena itu, dapat dikatakan tidak ada perbedaan antara nilai rangking sebelum dan sesudah diaplikasikannya sistem penilaian kinerja berbasis kompetensi perawat gawat darurat. Oleh karena tidak ada perbedaan antara nilai rangking sebelum dan sesudah diaplikasikannya sistem penilaian kinerja berbasis kompetensi perawat gawat darurat, maka sistem penilaian kinerja
Tabel 1. Hasil Penilaian Kinerja

\begin{tabular}{|c|c|c|c|}
\hline \multirow{2}{*}{ RSU } & \multirow{2}{*}{ Sampel } & \multicolumn{2}{|c|}{ Rangking } \\
\hline & & Sebelum & Sesudah \\
\hline \multirow{5}{*}{ Malahayati } & 1 & 2 & 3 \\
\hline & 2 & 4 & 2 \\
\hline & 3 & 5 & 4 \\
\hline & 4 & 3 & 5 \\
\hline & 5 & 1 & 1 \\
\hline \multirow{7}{*}{ Bina Kasih } & 1 & 2 & 1 \\
\hline & 2 & 5 & 5 \\
\hline & 3 & 4 & 7 \\
\hline & 4 & 1 & 2 \\
\hline & 5 & 6 & 4 \\
\hline & 6 & 3 & 3 \\
\hline & 7 & 7 & 6 \\
\hline \multirow{5}{*}{ Sari Mutiara } & 1 & 3 & 2 \\
\hline & 2 & 4 & 4 \\
\hline & 3 & 5 & 5 \\
\hline & 4 & 2 & 3 \\
\hline & 5 & 1 & 1 \\
\hline \multirow{8}{*}{ Permata Bunda } & 1 & 1 & 6 \\
\hline & 2 & 2 & 3 \\
\hline & 3 & 5 & 7 \\
\hline & 4 & 3 & 8 \\
\hline & 5 & 6 & 1 \\
\hline & 6 & 8 & 5 \\
\hline & 7 & 7 & 4 \\
\hline & 8 & 4 & 2 \\
\hline \multirow{11}{*}{ Deli } & 1 & 5 & 3 \\
\hline & 2 & 7 & 4 \\
\hline & 3 & 10 & 6 \\
\hline & 4 & 11 & 11 \\
\hline & 5 & 1 & 1 \\
\hline & 6 & 9 & 10 \\
\hline & 7 & 8 & 9 \\
\hline & 8 & 4 & 2 \\
\hline & 9 & 6 & 8 \\
\hline & 10 & 3 & 7 \\
\hline & 11 & 2 & 5 \\
\hline \multirow{10}{*}{ Imelda } & 1 & 10 & 10 \\
\hline & 2 & 7 & 7 \\
\hline & 3 & 1 & 1 \\
\hline & 4 & 2 & 2 \\
\hline & 5 & 4 & 4 \\
\hline & 6 & 11 & 11 \\
\hline & 7 & 9 & 9 \\
\hline & 8 & 5 & 5 \\
\hline & 9 & 3 & 3 \\
\hline & 10 & 6 & 6 \\
\hline \multirow{17}{*}{ Martha Friska } & 1 & 16 & 16 \\
\hline & 2 & 13 & 13 \\
\hline & 3 & 3 & 3 \\
\hline & 4 & 8 & 8 \\
\hline & 5 & 10 & 10 \\
\hline & 6 & 7 & 7 \\
\hline & 7 & 4 & 4 \\
\hline & 8 & 12 & 12 \\
\hline & 9 & 15 & 15 \\
\hline & 10 & 6 & 6 \\
\hline & 11 & 2 & 2 \\
\hline & 12 & 1 & 1 \\
\hline & 13 & 9 & 9 \\
\hline & 14 & 11 & 11 \\
\hline & 15 & 14 & 14 \\
\hline & 16 & 5 & 5 \\
\hline & 17 & 17 & 17 \\
\hline
\end{tabular}


Tabel 2. Hasil Analisis Uji Wilcoxon

\begin{tabular}{ll}
\hline Sesudah-Sebelum & \\
\hline $\mathbf{Z}$ & $-0,52$ \\
Asymp. Sig. (2-tailed) & 0,959 \\
\hline
\end{tabular}

berbasis kompetensi perawat gawat darurat yang telah dibuat pada tahun pertama, secara umum dinyatakan valid.

Jika dilihat pada masing-masing RSU swasta, RSU Swasta Imelda, dan RSU Swasta Martha Friska rangking sebelum penilaian kinerja yang telah dibuat pada tahun pertama sama dengan sesudah penerapan penilaian kinerja yang telah dibuat pada tahun pertama, jadi tidak dilakukan uji statistik, sedangkan 5 RSU Swasta yang lain yaitu RSU Swasta Malahayati, RSU Swasta Bina Kasih, RSU Swasta Sari Mutiara, RSU Swasta Permata Bunda, dan RSU Swasta Deli, rangking sebelum aplikasi penilaian kinerja yang telah dibuat pada tahun pertama ada yang sama dengan sesudah aplikasi penilaian kinerja yang telah dibuat pada tahun pertama dan ada yang tidak. Maka untuk ke-lima RSU swasta ini dilakukan analisis univariat dan bivariat.

Hasil uji normalitas menunjukkan bahwa nilai sig. sebelum dan sig. sesudah pada ke-lima RSU swasta lebih besar dari $\alpha=0,05$, maka dapat disimpulkan bahwa sebaran data normal. Oleh karena itu, dilanjutkan dengan analisis bivariat dengan uji $t$ dependent untuk mengetahui perbedaan antara nilai rangking sebelum dan sesudah diaplikasikannya sistem penilaian kinerja berbasis kompetensi perawat gawat darurat di ke-lima RSU swasta tersebut. Tabel 3, dapat dilihat bahwa nilai p pada ke-lima RSU swasta lebih besar dari 0,05 . Oleh karena itu, dapat dikatakan tidak ada perbedaan antara nilai rangking sebelum dan sesudah diaplikasikannya sistem penilaian kinerja berbasis kompetensi perawat gawat darurat pada ke-lima RSU swasta tersebut. Oleh karena tidak ada perbedaan antara nilai rangking sebelum dan sesudah diaplikasikannya sistem penilaian kinerja berbasis kompetensi perawat gawat darurat, maka sistem penilaian kinerja yang telah dibuat pada tahun pertama pada ke-lima RSU swasta tersebut, dinyatakan valid.

\section{PEMBAHASAN}

Uji validasi dilakukan untuk mengetahui kevalidan prototipe yang dibangun sehingga dapat memberikan hasil penilaian kinerja perawat gawat darurat yang valid. Uji validasi dilakukan dengan membandingkan hasil penilaian kinerja perawat gawat darurat yang telah dilakukan secara manual sebelumnya. Konsep validitas telah berkembang menjadi "sejauh mana bukti dan teori mendukung interpretasi hasil tes sesuai dengan tujuan dari tes tersebut". Sebuah penilaian kinerja hanya dapat dianggap sah sejauh bukti dapat diberikan untuk mendukung interpretasi atau makna dikaitkan dengan penilaian. Oleh karena itu, tes tidak bisa $d i-$ chotomously mengklaim menjadi tes yang bagus atau tes yang buruk karena itu tergantung pada bukti yang membenarkan penggunaan tes dan bagaimana hasilnya akan ditafsirkan. ${ }^{12,13}$

Berdasarkan hasil penelitian diperoleh bahwa sistem penilaian kinerja yang telah dibuat pada tahun pertama dinyatakan valid. Hasil uji statistik menunjukkan bahwa tidak ada perbedaan antara nilai rangking sebelum dan sesudah diaplikasikannya sistem penilaian kinerja berbasis kompetensi perawat gawat darurat. Hal ini dikarenakan penilaian kinerja berbasis kompetensi perawat gawat darurat yang dirancang pada tahun pertama dibuat secara konkret dalam bentuk yang dapat didokumentasikan dari penilaian kinerja yang lama. Hal ini sesuai dengan pendapat Aamodt, Bernardin dan Beatty, Mudayana, bahwa penilaian kinerja harus mampu memberikan gambaran yang akurat dan objektif mengenai kinerja karyawan dan hasil penilaian kinerja harus dapat didokumentasikan. ${ }^{8,14,15}$

Tabel 3. Uji T Dependent di masing-masing 5 Rumah Sakit

\begin{tabular}{cccccc}
\hline & \multicolumn{5}{c}{ Paired Samples Test } \\
& Asymp. Sig. (2-tailed) \\
\cline { 2 - 6 } & $\begin{array}{c}\text { RSU Swasta } \\
\text { Malahayat }\end{array}$ & $\begin{array}{c}\text { RSU Swasta } \\
\text { Bina Kasih }\end{array}$ & $\begin{array}{c}\text { RSU Swasta } \\
\text { Sari Mutiara }\end{array}$ & $\begin{array}{c}\text { RSU Swasta } \\
\text { Permata Bunda }\end{array}$ & $\begin{array}{c}\text { RSU Swasta } \\
\text { Deli }\end{array}$ \\
\hline Sebelum-Sesudah & 1,000 & 1,000 & 0,688 & 1,000 & 1,000 \\
\hline
\end{tabular}


Hal ini juga disebabkan penilaian kinerja berbasis kompetensi perawat gawat darurat yang dirancang pada tahun pertama melengkapi kekurangan yang ada pada lembar penilaian kinerja yang lama, seperti tujuan penilaian kinerja, tempat tandatangan perawat gawat darurat yang dinilai, memberikan bobot untuk setiap kompetensi, penilaian kinerja lebih fokus pada kompetensi, dan memaksa atasan dari perawat gawat darurat untuk menggunakan lembar penilaian untuk menilai perawat gawat darurat paling tidak 6 bulan sekali. Hal ini sesuai dengan pendapat Aamodt bahwa penilaian kinerja harus jelas tujuannya, karyawan yang dinilai mengetahui hasil penilaian kinerja, lembar penilaian kinerja yang terbaik itu disusun berdasarkan kompetensi dan masing-masing memiliki bobot yang berbeda-beda untuk setiap kompetensinya yang pelaksanaannya dilakukan sekali 6 bulan, sehingga atasan ataupun karyawan yang dinilai lebih cepat memperbaiki kompetensi mana yang kurang dari diri karyawan itu tersebut. ${ }^{8}$

Begitu juga pendapat dari Wijayanti dan Wimbarti, kejelasan tujuan, penerimaan, komitmen, kepuasan dalam proses penilaian, serta peningkatan dalam melakukan unjuk kerja merupakan hal-hal yang dapat dipengaruhi oleh bentuk-bentuk penilaian yang diterapkan, keterlibatan dan partisipasi karyawan dalam menentukan faktor-faktor penilaian serta proses pembuatan sistem penilaian dapat meningkatkan persepsi keadilan prosedur yang juga dapat meminimalisir bias. ${ }^{3}$

Perawat gawat darurat yang dinilai harus mengetahui hasil penilaian kinerja mereka karena dengan umpan balik dapat meningkatkan kualitas kinerja dari perawat tersebut. Akan tetapi, hal ini dapat terjadi jika perawat tersebut menerima dan menganggap bahwa penilaian kinerja yang dilakukan merupakan sumber informasi yang dapat menolong mereka sendiri untuk memperbaiki kinerja mereka. Hal ini dapat terjadi jika hasil penilaian kinerja perawat diberitahukan kepada mereka dengan proses yang baik disertai dengan penjelasan-penjelasan mengenai hasil penilaian dan bagaimana meningkatkan kinerja mereka. ${ }^{16}$

Hasil penelitian Takase, Maude dan Manias, menunjukkan bahwa jika perawat tidak diikutsertakan dalam pengambilan keputusan yang berkaitan dengan pekerjaan mereka maka akan menimbulkan rasa ketidakpuasan dan kemung- kinan bisa mengakibatkan turnover ${ }^{17}$ Oleh karena itu, hasil penilaian kinerja ini harus diberikan dengan baik kepada perawat gawat darurat sehingga terciptanya kepuasan kerja dan akan mengurangi tingkat ketidak hadiran, meningkatkan retensi, dan meningkatkan kepuasan pasien sebagai pelanggan. ${ }^{18}$

\section{KESIMPULAN DAN SARAN}

Rancangan sistem penilaian kinerja berbasis kompetensi perawat gawat darurat, yang telah dibuat pada tahun pertama di 7 RSU swasta yang menjadi partisipan, dinyatakan valid $(\mathrm{p}=0,959>0,05)$. Penilaian kinerja yang disusun pada tahun pertama sepadan dengan penilaian kinerja yang lama. Oleh karena itu, disarankan bagi direktur atau manajemen sumber daya manusia di 7 RSU swasta yang menjadi partisipan agar mempergunakan penilaian kinerja berbasis kompetensi perawat gawat darurat ini sekali dalam 6 bulan dan hasil penilaiannya dapat dipergunakan untuk rekrutmen, pendidikan, pelatihan dan promosi perawat gawat darurat di masing-masing RSU Swasta.

\section{DAFTAR PUSTAKA}

1. Silaban, G., Lubis, A. M., Salmah, U. Perancangan Sistem Penilaian Kinerja Berbasis Kompetensi Perawat Gawat Darurat di RSU Herna Medan. Jurnal Kesehatan Masyarakat Andalas. 2015;10(1):59-64.

2. Daoanis, L. E. Performance Appraisal System: It's Implication to Employee Performance. International Journal of Economics and Management Sciences. 2012;2(3):55-62.

3. Wijayanti, A., Wimbarti, S. Evaluasi dan Pengembangan Sistem Penilaian Kinerja pada PT HKS. Jurnal Psikologi Undip. 2012;11(2).

4. Sulistyawan, F., Wurijanto, T., Subiyantoro, Y. Y. Sistem Informasi Penilaian Kinerja Pegawai Menggunakan Metode Graphic Rating Scales dan 360 Derajat. Jurnal Sistem Informasi, Jsika. 2013;2:7-13.

5. Grealish, L. How Competency Standards Became The Preferred National Technology for Classifying Nursing Performance in Australia. Australian Journal of Advanced Nursing. 2013;30(2): 20-31.

6. Silaban, G., Lubis, A. M., Salmah,U. Laporan Penelitian Perancangan Sistem Penilaian 
Kinerja Berbasis Kompetensi Perawat Gawat Darurat di RSU Swasta se Kota Medan. 2015. Medan: LP3M USU.

7. Sundaramoorthi, D., Chen, V. C. P., Rosenberger, J. M., Kim, S. B., Buckley-Behan, D.F. A Data-Integrated Simulation Model to Evaluate Nurse-Patient Assignments. Health Care Manage Sci. 2009;12:252-268. DOI 10.1007/ s10729-008-9090-7.

8. Aamodt, M.G. Industrial/Organizational Psychology an Applied Approach, $8^{\text {th }}$ ed, USA: Cengage Learning 2016.

9. Koeswanto, C. A. Strategi Pengembangan Bisnis pada PT. Putrasean Rubber Industri, AGORA. 2016;4(2).

10. Dargham, N. A. S. Effective Management of the Performance Appraisal Process in Lebanon: an Exploratory Study. Maître de Conférences à la FGM, (pp. 1-24). [Online Journal] 2008; [diakses 30 September 2016]. Available at: http://www.fgm.usj.edu. lb/pdf/ a12008.pdf

11. Spencer, L. M., Spencer, S. M. Competence at Work: Models for Superior Performance. USA: John Wiley \& Sons, Inc;1993.

12. Savitri, I. A., Dania, W. A., Ikasari, D. M. Penilaian Kinerja Karyawan dengan Model Fuzzy Multi Attribute Decision Making Metode Simple Additive Weighted (Studi Kasus pada Rumah Makan Kober Mie Setan Malang). Jurnal Lulusan TIP FTP UB. September 2014. [Online Journal] 2014; [diakses 27 Nopember 2016]. Available at: http:// skripsitip.staff.ub.ac.id/files/2014/09/Irma-Ayu-Savitri.pdf
13. Thompson, G. A., Moss, R., Applegate, B.. Using Performance Assessments to Determine Competence in Clinical Athletic Training Education: How Valid are Our Assessments?. Athletic Training Education Journal. 2014;9(3):135-141. ISSN: 1947-380X, DOI: 10.4085/0903135.

14. Moorhead, G., Griffin, R.W. Perilaku Organisasi: Manajemen Sumber Daya Manusia dan Organisasi, Jakarta: Salemba Empat. 2013.

15. Mudayana, A. A. Hubungan Beban Kerja dengan Kinerja Karyawan di RS Nur Hidayah Bantul. Universitas Ahmad Dahlan. KESMAS. 2012;6(1):1-74, ISSN: 1978-0575.

16. Giesbers, S., Schouteten, R. L. J., Poutsma, E., van der Heijden, B. I.J.M., van Achterberg, T. Nurses' Perception of Feedback on Quality Measurements: Development and Validation of a Measure. Zeitschrift für Personalforschung/ German Journal of Research in Human Resource Management, Jahrg. 28, H. 3 (2014), pp. 391-398. ISSN (print) 0179-6437, ISSN (internet) 1862-0000. DOI 10.1688/ZfP2014-03-Giesbers.

17. Takase, M. Maude, P., Manias, E. Comparison between Nurses' Professional Needs and Their Perceptions of Their Job. Australian Journal of Advanced Nursing. 2005;23(2):28.

18. Palese, A., Balboni, B., Dante, A., Tonzar, L. The N2N Instrument to Evaluate Healthy Work Environments: an Italian Validation. International Archives of Occupational and Environmental Health. February 2014;87(2):217-22. DOI 10.1007/s00420-013-0851-3. 